10IKC-188

\title{
ELEMENT DIFFUSION IN COMPOSITE XENOLITHS FROM ALKALINE BASALTS (WEST SANGILEN, RUSSIA)
}

\author{
Gibsher $^{1 *}$ AA, Malkovets ${ }^{1}$ VG, Kuzmin DV ${ }^{1,2}$, Griffin $^{3}$ WL, O'Reilly ${ }^{3}$ SY \\ ${ }^{I}$ V.S. Sobolev Institute of Geology and Mineralogy, Novosibirsk, Russia \\ ${ }^{2}$ Max-Planck Institute of Chemistry, Postfach 3060, Mainz, 55020, Germany \\ ${ }^{3}$ GEMOC National Key Centre, Macquarie University, Sydney, Australia
}

\section{INTRODUCTION}

Mantle metasomatism has been ncreasngly recognsed as a significant process among petrologists in recent years. Metasomatic events in mantle xenoliths and ultramafic massifs are observed as trace-element enrichment unaccompanied by mineralogical changes cryptic metasomatism (Dawson, 1984), or as addition of new minerals- modal metasomatism (Harte, 1983). Commonly metasomatic enrichment in mantle xenoliths carried up to the surface by kimberlites and alkali basalts is recorded in trace-element changes. Composite xenoliths showing contacts between two or more different rock types are uncommon, ut they are a source of unique information about the migration of melts and their interaction with the mantle matrix (Mantle metasomatism, 1987).

Our collection of mantle xenoliths includes composite xenoliths exhibiting contacts between spinel lherzolite and clinopyroxenite $( \pm$ phlogopite \pm amphibole). We report in this paper the results of major- and trace-element study of clinopyroxenes and olivines in composite mantle xenoliths of lherzolite cross-cut by phlogopiterich pyroxenite veins. Our data allow us to estimate the thickness of metasomatic zones and the distribution and fractionation of trace elements between vein and wall-rock.

\section{GEOLOGICAL SETTING}

The West Sangilen belt is a Cambrian-
Ordovician collisional orogen, which has been formed as a result of the accretion of theTannuola island arc, Agardag back-arc basin and Sangilen microcontinent (Fig.1). A local area of camptonite dykes was discovered in the western part of West Sangilen. Camptonite dikes represent the plutonic end member in the region. The Ar-Ar dating of lamprophyres gave Ordovician ages of $440 \mathrm{Ma}$ (Izokh et al., 2001). Camptonite transports to the surface numerous large (up to $70 \mathrm{~cm}$ in diameter) fresh xenoliths of lherzolites, pyroxenites, and various megacrysts.

\section{SAMPLES}

Xenoliths of peridotite comprise samples only of the spinel facies. The modal and bulk

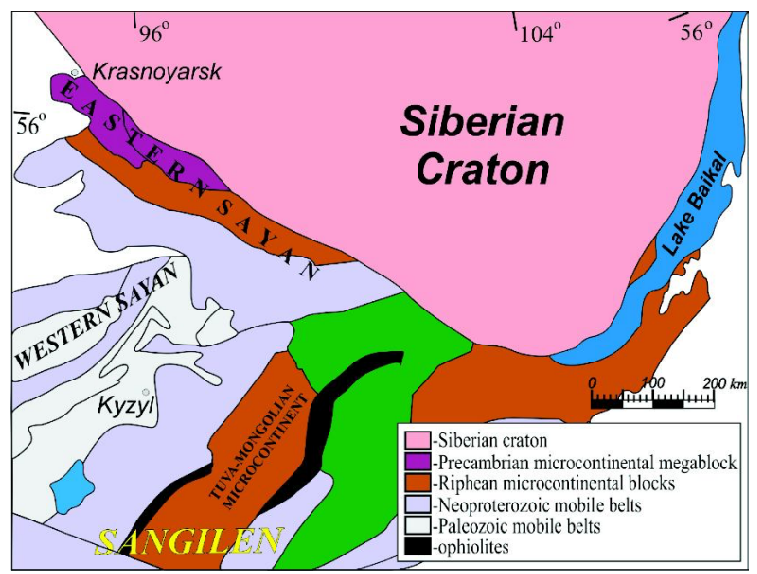

Fig. 1. Simplified tectonic scheme of the central part of the Central Asian Orogenic Belt (modified after Gibsher et al., 2000). 


\section{0 $^{\text {th }}$ International Kimberlite Conference, Bangalore - 2012}

compositions of lherzolites from West Sangilen are close to typical fertile lherzolites carried to the surface by early Ordovician alkaline basaltoids (Gibsher et al., 2010). In the lherzolite xenoliths, the $\mathrm{Mg} \#$ of olivine $(\mathrm{Mg} \#=100 \mathrm{Mg} /(\mathrm{Mg}+\mathrm{Fe}))=$ $88.8-91.2 \%$, the $\mathrm{NiO}=0.29-0.38$ wt $\%$, and $\mathrm{CaO}=0.06-0.12 \mathrm{wt} \%$. Clinopyroxenes are chromium diopside, in which concentrations of $\mathrm{Cr}_{2} \mathrm{O}_{3}=0.63-1.88$ wt. \%, $\mathrm{Al}_{2} \mathrm{O}_{3}=7.6-2.1$ wt. $\%, \mathrm{Na}_{2} \mathrm{O}=2.2-0.4$ wt. $\%, \mathrm{TiO}_{2}=0.97-0.05$ wt. $\%$ and $\mathrm{Mg} \#=88.7-92.8$. The Mg-numbers of orthopyroxenes range from 89.3 to 91.9 . Spinels are characterized by a wide range in both $\mathrm{Mg \#}$ (from 62.7 to 80.3) and $\mathrm{Cr}_{2} \mathrm{O}_{3}$ content (8.18-47.9 wt \%).

A composite xenolith studied in detail (sample 5H759) is a lherzolite (olivine + clinopyroxene + orthopyroxene) with a selvage (clinopyroxene + phlogopite). The widths of the selvage and lherzolite in the sample are 4 and 21 $\mathrm{mm}$, respectively. Orthopyroxene is absent within $10 \mathrm{~mm}$ from the contact (Fig. 2).

Another lherzolite sample (5H79) was investigated for comparative purposes as a typical unmetasomatised peridotite matrix (Gibsher et al., 2010). 5H79 is a spinel lherzolite with protogranular texture and without water-bearing minerals. In olivine the $\mathrm{Mg} \#=90.7$, the $\mathrm{CaO}=$ 0.9 wt. $\%$, and $\mathrm{NiO}=0.36$ wt. $\%$. In clinopyroxene the $\mathrm{Mg} \#=92$, the $\mathrm{SiO}_{2}=52.8$ wt. $\%, \mathrm{TiO}_{2}=0.08$ wt. $\%, \mathrm{Al}_{2} \mathrm{O}_{3}=3.7$ wt. $\%, \mathrm{MgO}=17.3$ wt. $\%$, ÑâI $=20.8$ wt. $\%, \mathrm{Cr}_{2} \mathrm{O}_{3}=1.34$ wt. $\%$. The temperature of equilibrium for the mineral parageneses of $5 \mathrm{H} 79$ is $1059{ }^{i} \tilde{\mathrm{N}}$ (BKN, Brey \& Kohler, 1990) and $1037^{ } \mathrm{N}$ (Ca-OPx, Brey \& Kohler, 1990).

\section{ANALYTICAL METHODS}

The contents of the major and trace elements in olivines and clinopyroxenes were determined by EMPA using a Jeol 8200 Super Probe at Max Planck Institute for Chemistry, Mainz, Germany using a method described by Sobolev et al. (2007). The contents of the trace elements in

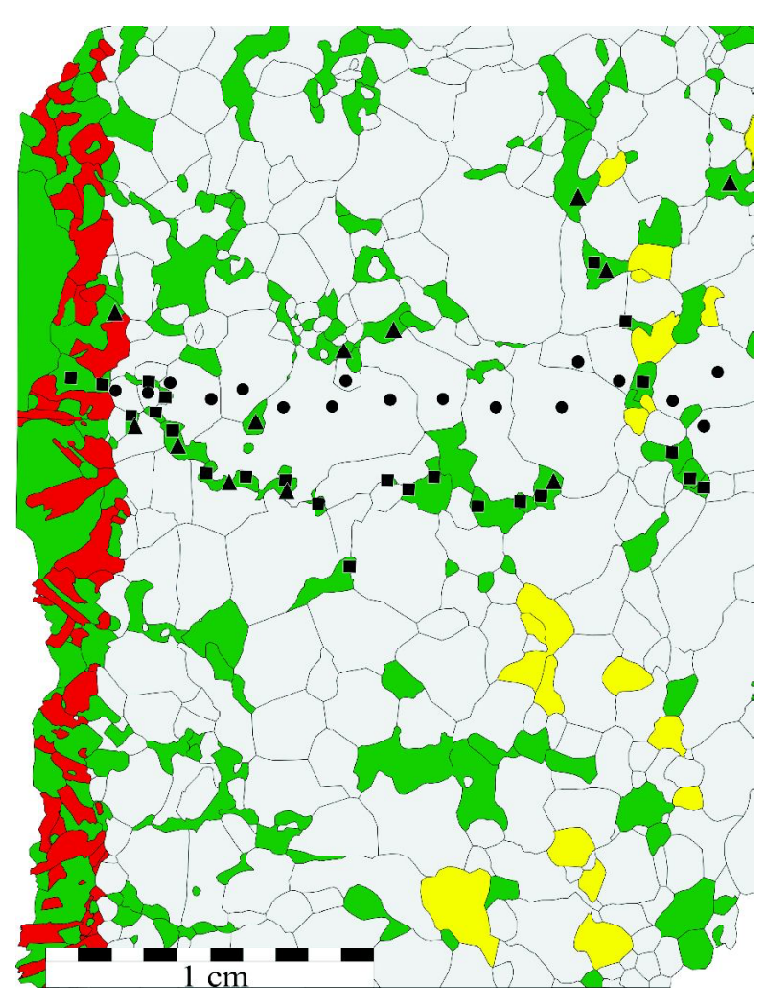

Fig 2. Composite xenolith showing contact between phlogopite pyroxenite (left) and spinel lherzolite (right). Green - clinopyroxene, grey - olivine, yellow - orthopyroxene, red - phlogopite. Circle EMP olivine, square - EMP clinopyroxene, triangle - LA-ICP-MS clinopyroxene.

clinopyroxenes were determined by LA-ICP-MS (New Wave Merchanteck, UP-213) using an Agilent 7500s at GEMOC, Sydney, Australia and methods described by Norman et al. (1996).

\section{MAJOR AND TRACE ELEMENT COMPOSITION}

The content of major elements in olivines and clinopyroxenes along the profile from the contact to the periphery of the sample is shown in Figure 3. Olivine $\mathrm{Mg} \#$ varies only from 89.6 to 89.7, $\mathrm{NiO}$ content from 0.334 to 0.344 wt. \%, $\mathrm{Cr}_{2} \mathrm{O}_{3}$ from 0.011 to 0.02 wt. \%, $\mathrm{TiO}_{2}$ content falls from 0.014 to 0.009 wt. $\%$ and $\mathrm{CaO}$ from 0.102 to $0.094 \mathrm{wt}$. \% from the contact to the periphery of the sample (Fig. 3). In clinopyroxenes Mg\# 
increases from 89.2 to $89.6, \mathrm{SiO}_{2}$ content from 50.3 to $51.5 \mathrm{wt}$ \%, $\mathrm{MnO}$ from 0.087 to $0.114 \mathrm{wt}$. $\%, \mathrm{MgO}$ from 15.4 to 16.1 wt. $\%, \mathrm{Cr}_{2} \mathrm{O}_{3}$ from 0.43 to 0.97 wt. $\%, \mathrm{TiO}_{2}$ content decreases from 1.3 to 0.6 wt. $\%$, and $\mathrm{Al}_{2} \mathrm{O}_{3}$ from 7.8 to 6.5 wt. $\%$ (Fig. 3).
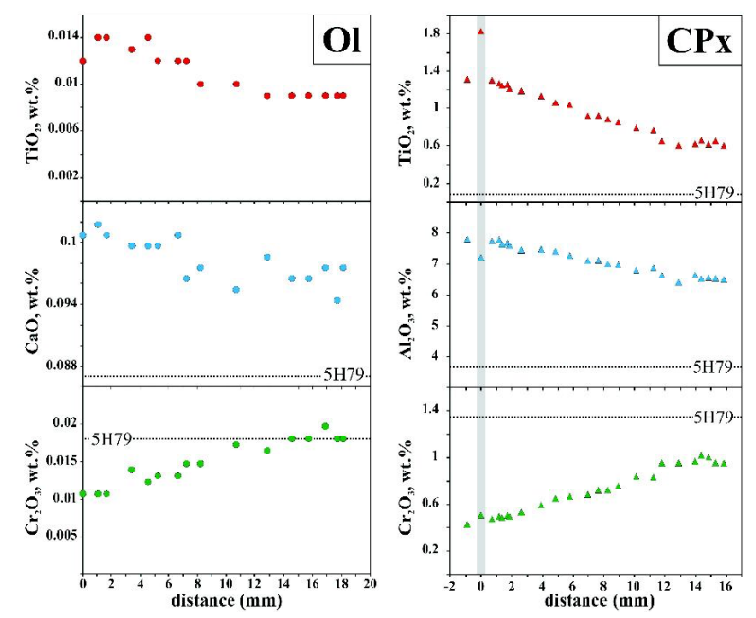

Fig 3. Variations of olivine and clinopyroxen major-element compositions in composite xenolith. Vertical grey line - contact between pyroxenite (left) and lherzolite (right). Dotted line unmetasomatised lherzolite $5 \mathrm{H} 79$.

Equilibrium temperatures for mineral assemblages calculated by (BKN, Brey, Kohler, 1990) are $1116^{\circ} \mathrm{C}$ and by (Ca-OPx, Brey, Kohler, $1990)-1052^{\circ} \mathrm{C}$ at a distance of $10 \mathrm{~mm}$ from the contact.

The contents of trace elements in clinopyroxenes along the profile from the contact to the periphery of the sample are shown in Figure 4. The total content of incompatible elements in clinopyroxenes decreases with distance. However, the values corresponding to the clinopyroxene from unmetasomatised lherzolite 5H79 are not reached. Chondrite-normalized trace-element patterns of clinopyroxenes are shown in Fig. 5. Reduced concentrations for different elements are uneven. The most dramatic changes are in the contents of HFSE and MREE; for LREE and HREE this change is not so obvious, and for $\mathrm{Sr}$ is insignificant. Clinopyroxenes have $\mathrm{La} / \mathrm{Yb}$ ratios
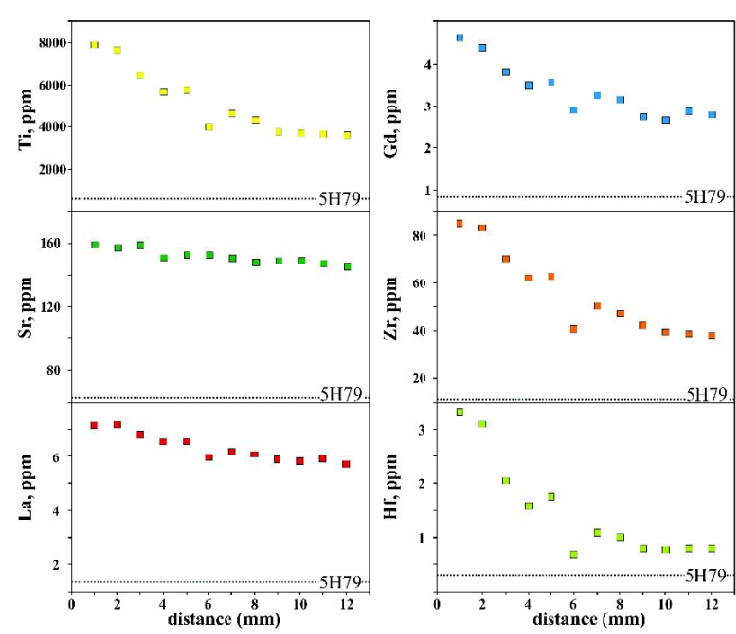

Fig 4. Variations of clinopyroxene trace-element compositions in lherzolite from composite xenolith. Dotted line - unmetasomatised lherzolite $5 \mathrm{H} 79$.

from 4.9 to 5.7. Clinopyroxenes near the contact are depleted in $\mathrm{Sr}$ and have patterns without negative $\mathrm{Zr}-\mathrm{Hf}-\mathrm{Ti}$ anomalies in chondritenormalized plots (black line in Fig. 5). Clinopyroxenes at a distance of $12 \mathrm{~mm}$ have negative Zr-Hf-Ti anomalies (white line in Fig.5).

There is a positive anomaly for $\mathrm{Hf} *=1 / 2$ $(\mathrm{Zr}+\mathrm{Ti})$ near the vein, which changes to negative at a distance of $10 \mathrm{~mm}$ from the vein. The contents of $\mathrm{Zr}$ and $\mathrm{Ti}$ fall together with $\mathrm{Hf}$. The $\mathrm{Zr} / \mathrm{Hf}$ ratio increases sharply from 26 to 60 at $9 \mathrm{~mm}$ from the

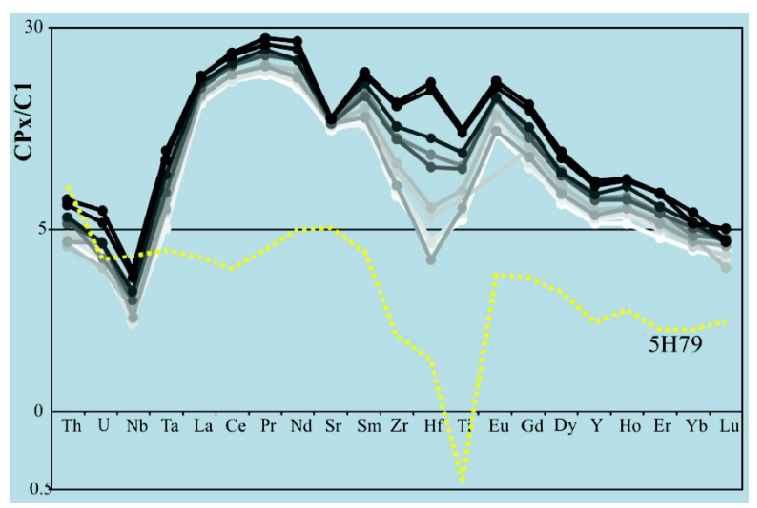

Fig. 5. Chondrite-normalized trace-element patterns of clinopyroxenes from contact (black) to periphery (white), and in unmetasomatised lherzolite 5H79 (yellow dotted line). Normalization values are from McDonough \& Sun (1995). 
vein, and then gradually falls to 48 . These elements are probably accounted for in ilmenite, phlogopite or microphases in intergrains (Zanetti et al., 1996; Jinhai et al., 2006).

To estimate the diffusion activity of various components, we used a normalized concentration ratio, according to the method described in Zanetti et al. (1996). $\mathrm{Z}=\left(\mathrm{C}-\mathrm{C}_{\mathrm{o}}\right) /\left(\mathrm{C}_{\mathrm{m}}-\mathrm{C}_{\mathrm{o}}\right)$, where $\mathrm{C}-$ concentration of the element in clinopyroxene, $\mathrm{C}_{\mathrm{o}}$ - concentration in clinopyroxene from unmetasomatised sample (in this case lherzolite 5H79), $\mathrm{C}_{\mathrm{m}}$ - concentration in clinopyroxene from the vein. Plots of this parameter with distance show the relative diffusability of different elements (Fig. 6).

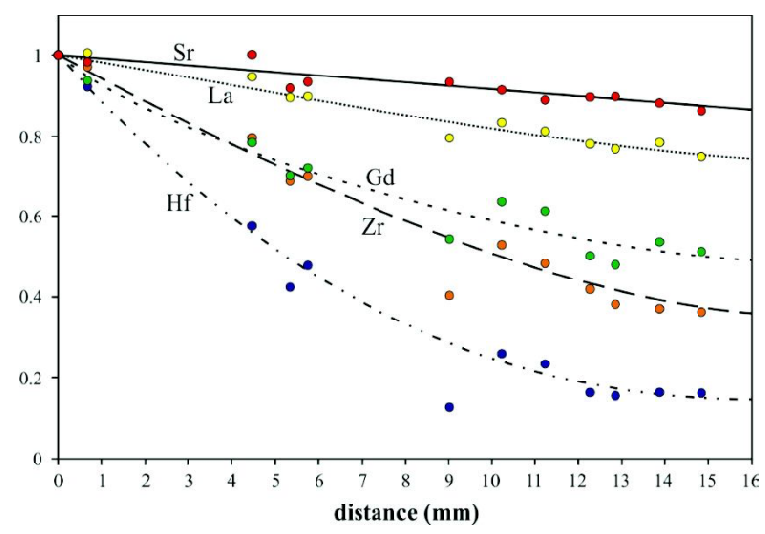

Fig. 6. Correlation diagrams of $Z=\left(C-C_{0}\right) /\left(C_{m}-C_{0}\right)$ and distances.

$\mathrm{Z}$ (Sr) slightly decreases with increasing distance from the contact, and $\mathrm{Z}(\mathrm{Hf})$ on the contrary decreases very sharply. The unequal decrease in the content of trace elements in clinopyroxenes from the contact to the periphery indicates the fractionation of elements in the metasomatic fluid, which is most strongly depleted in $\mathrm{Zr}$, Hf, Ti and enriched in Sr, La (Fig. 4-6). In accordance with this plot, we can build a series of mobility of elements in metasomatic fluid: $\mathrm{Z}(\mathrm{Sr})>\mathrm{Z}(\mathrm{La})>\mathrm{Z}(\mathrm{Gd})>\mathrm{Z}(\mathrm{Zr})>\mathrm{Z}(\mathrm{Hf})$. This is consistent with the findings on a number of mobile elements made by Jinhai et al. (2006). However, the lherzolite sample studied here is only $2 \mathrm{~cm}$ wide; we cannot observe the full equalization of concentrations to a level of unmetasomatised lherzolite 5H79.

\section{CONCLUDING REMARKS:}

1) Results of high-precision determination of impurities in olivines indicate that cryptic metasomatic enrichment in contact with the vein is evident not only for clinopyroxene, but to some extent in olivine as well.

2) The degree of mobility of elements in the metasomatic fluid decreases in the series $\mathrm{Sr}>\mathrm{La}>\mathrm{Gd}>\mathrm{Zr}>\mathrm{Hf}$.

3) Under conditions of "hydrous" metasomatism the width of the metasomatic zone exceeds the sample size in our case. The incompatibleelement contents in clinopyroxene from the most distant part of the sample are still higher than in clinopyroxenes from the set of well studied mantle xenoliths from this location.

\section{References}

Dawson, J.B. (1984) In "Kimberlites - II. The Mantle and Crust/Mantle Relationships" (J Kornprobst, ed), Developments in Petrology Series, 11B, pp. 290-294. Elsevier, Amsterdam.

Harte, B (1983) In "Continental Basalts and Mantle Xenoliths" (C.J. Hawkesworth and M.J. Norry, eds), pp. 46-91. Shiva Publishing Ltd, Nantwich, Cheshire, UK.

Mantle Metasomatism - M.A. Menzies and C.J. Hawkesworth (eds) (1987)

Gibsher A.S.; Vladimirov A.G., Vladimirov V.G. (2000). The geodynamic nature of Early Pa-leozoic nappe-folded structure of Sangilen upland (SouthEastern Tuva), Dokl Akad Nauk, 370, 489-492.

Izokh, A.E., Polyakov, G. V., Mal'kovets, V. G., Shelepaev, R. A., Travin, A. V., Litasov, Yu. D., Gibsher, A. A. (2001) The Late Ordovician Age of Camptonites from the Agardag Complex of Southeastern Tuva as an Indicator of the PlumeRelated Magmatism during Collision Processes. Doklady Earth Sciences, v. 379, No. 5, pp. 511514. 
Gibsher, A. A., Malkovets, V. G., Litasov, K. D., Litasov, Yu. D., Pokhilenko, N. P. (2010) Composition of the Ordovician Lithospheric Mantle: Evidence from the Study of Peridotite Xenoliths from Camptonite of the Sangilen Highland, Central Asian Fold Belt. Doklady Earth Sciences, v. 433, Part 1, pp. 957-961.

Brey, G.P., Köhler T. (1990) Geothermobarometry in four-phase lherzolites II. New thermobarometers, and practical assessment of existing thermobarometers. Journal of Petrology, v. 31, pp. 1353-1378.

Sobolev, A.V., Hofmann, A.W., Kuzmin, D.V., Yaxley, G.M., Arndt, N. T., Chung, S.L., Danyushevsky, L. V., Elliott, T., Frey, F. A., Garcia, M. O., Gurenko, A. A., Kamenetsky, V. S., Kerr, A. C., Krivolutskaya, N. A., Matvienkov, V. V., Nikogosian, I. K., Rocholl, A., Sigurdsson, I. A., Sushchevskaya, N. M., Teklay, M (2007) The Amount of Recycled Crust in Sources of MantleDerived Melts. Science, v. 316, pp. $412-417$.
Norman, M.D., Pearson, N.J., Sharm,a A., Griffin, W.L. (1996) Quantitative analysis of trace elements in geological materials by laser ablation ICPMS: instrumental operating conditions and calibration values of NIST glasses. Geostandards Newsletter, v. 20 , p. $247-261$.

Jinhai,Y.U., O’Reilly, S.Y., Xisheng, X.U., Rucheng, W. (2006) Element diffusion ability in metasomatic agents and its effect on chemical characteristics of metasomatized peridotites. Science in China Series D: Earth Sciences, v.49, No.9, pp. 926-937.

McDonough, W.F., Sun, S.-S. (1995) The composition of the earth. Chemical Geology, v. 120, pp. 223253.

Zanetti, A., Vanucci, R., Bottazzi, P., Oberti, R., Ottolini, L. (1996) Infiltration metasomatism at Lherz as monitored by systematic ion-microprobe investigations close to a hornblendite vein. Cemical Geology, v. 134, pp. 113-133. 